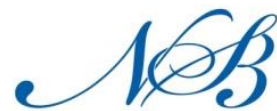

Notulae Scientia Biologicae

\title{
Partial Purification and Characterisation of Alcohol Dehydrogenase from Acetobacter aceti Isolated from Palm Wine
}

\author{
Donatus Chimaobi ONAH ${ }^{1}$, Sabinus Oscar O. EZE ${ }^{1}$, Patrick Emeka ABA
}

\author{
IUniversity ofNigeria,Nsukka,DepartmentofBiochemistry,EnuguState,Nigeria;donchimaobi@yahoo.com;sabinus.eze@unn.edung \\ ${ }^{2}$ University of Nigeria, Nsukka, Department of VeterinaryPhysiology andPharmacology,EnuguState, Nigeria;patrickaba@unn.edu.ng("correspondingauthor)
}

\begin{abstract}
Palm wine is a very important alcoholic beverage whose consumption is limited because it spoils easily. The study was designed to isolate Acetobacter aceti from palm wine, then extract, purify and characterize alcohol dehydrogenase (AD) from the $A$. aceti. Muller Hilton agar was used as medium for the growth of $A$. aceti for $48 \mathrm{~h}$. The cells were harvested and subjected to ultrasonication using 500 watt ultrasonicator. Enzyme assay was carried out in both the supernatant and pellet. The enzyme was precipitated by polyethelene glycol 6000 while gel filtration was used for purifying the enzyme. The effects of $\mathrm{pH}$, temperature and substrate concentration on $\mathrm{AD}$ were evaluated. The isolated $A$. acet $i$ was gram negative, rod shaped, catalase positive, oxidase negative and was able to oxidize acetic acid to $\mathrm{CO}_{2}$ and $\mathrm{H}_{2} \mathrm{O}$. Triton X-100 (0.3\%) was the most effective concentration in solubilizing the protein $(\mathrm{AD})$, while $15 \%$ polyethelene glycol 6000 was the most effective concentration for the precipitation of $\mathrm{AD}$. An optimal $\mathrm{pH}$ of 5 was obtained with an optimal temperature of $50{ }^{\circ} \mathrm{C}$. The most appropriate to solubilize and precipitate $\mathrm{AD}$ were $0.3 \%$ triton $\mathrm{X}-100$ and $15 \%$ polyethelene glycol 6000 respectively, while $\mathrm{AD}$ activity was reduced under acidic $\mathrm{pH}$, as well as for low and high temperatures.
\end{abstract}

Keywords: alcoholic beverage, alcohol dehydrogenase, bacteria, enzyme, isolation, palm wine, spoilage

\section{Introduction}

Palm wine is an important alcoholic beverage resulting from the spontaneous fermentation of the sap of palms, process that has been attributed to yeast and bacteria (Onwuka, 2011). Fresh palm wine is sweet, clear, neutral, colourless and contains minimal amount of sugar (less than $0.5 \%$ ), while it has valuable composition of protein, gums and minerals (Opara et al., 2013). In traditional African societies, the palm wine plays a significant role in customary practices, especially the distilled product from the palm wine, a potent gin called by various names in West Africa (Amoa-Awua et al., 2006), where over ten million people consume palm wine in West Africa (Onwuka, 2011). Traditionally, it is believed that when taken by nursing mothers, palm wine stimulates lactations and has also diuretic effect. Palm wine has been used to enhance potency in men due to yeast cell concentration. It is used in African medicine particularly in the treatment of measles and malaria (Onwuka, 2011).

Despite all these good qualities of palm wine, it is a highly perishable sap due to fermentation which starts soon after the sap is collected and within one-two hours becomes reasonably high in alcohol (up to $4 \%$ ). If palm wine is allowed to continue to ferment for more than 24 hours, it starts turning into vinegar. This makes it unacceptable for consumers and creates losses to the food service industries. Fermentation of palm wine is possible because it constitutes a good growth medium for numerous microorganisms, especially for yeast, lactic acid and acetic acid bacteria (Bechem et al., 2007). Bacteria induce the conversion of alcohol into vinegar (Onwuka, 2011).

Opara et al. (2013) had isolated Acetobacter from palm wine and these bacteria are believed to be responsible for souring of palm wine, which is not acceptable by many consumers. Acetic acid bacteria, Acetobacter and Gluconobacter, also known as vinegar producers, are able to oxidize ethanol to acetic acid by two sequential catalytic reactions of alcohol dehydrogenase and aldehyde dehydrogenase, which are located on the periplasmic side of their cytoplasmic membrane (Abolhassan et al., 2007).

Many unsuccessful attempts have been made to control palm wine spoilage at microbial level (Ojimelukwe, 2002; Enwefa $e t$ al., 2004). With increasing availability of modern methods efforts were directed towards the use of chemicals and pasteurization. Attempt to preserve palm wine using sulphite failed because the concentration of sulphite required to suppress microfloral activities would be excessive for human consumption. Moreover, the use of chemical preservatives is discouraged due to the danger of cancer promotion (Ojimelukwe, 2002).

In an attempt to control palm wine spoilage at enzyme level, researchers' attention was drawn to alcohol dehydrogenase, one of the enzymes in Acetobacter responsible for deterioration of palm wine by converting alcohol, the most wanted component of palm wine, into acetic acid. This entails that the enzyme can be isolated, purified and characterized, and that the effects of parameters such as $\mathrm{pH}$, temperature and ethanol concentration and their influence on the activity of alcohol dehydrogenase should be investigated.

The present study was therefore designed to isolate Acetobacter aceti from palm wine, extract alcohol dehydrogenase from the $A$. aceti and then partially purify and characterize the enzyme. 


\section{Materials and Methods}

\section{Preparation of liquid broth and mass production of Acetobacter aceti}

Muller Hilton agar (38 g) was dissolved in 1,000 ml of water and the mixture was allowed to settle. The containing agar settled to the bottom of the conical flask used. The mixture was filtered and the filtrate was autoclaved for $20 \mathrm{~min}$ at 15 psi pressure, $121^{\circ} \mathrm{C}$, in conical flasks. After cooling, pure $A$. aceti isolated from the palm wine, according to Maal and Shaifee (2010), was aseptically transferred from the medium onto the liquid broth, well covered and allowed to grow for 48 hours.

\section{Cells harvesting}

Bacteria cells were harvested by centrifugation at $4,000{ }^{*} \mathrm{~g}$ for $10 \mathrm{~min}$ and washed with cold water. The cell pastes were suspended in $0.01 \mathrm{M}$ potassium phosphate buffer, $\mathrm{pH} 6.0$ (1 g of wet cell/10 ml of buffer) (Adachi et al., 1978).

\section{Homogenization of cells}

The harvested cells (already suspended in $0.01 \mathrm{M}$ potassium phosphate buffer, $\mathrm{pH}$ 6.0) were subjected to ultrasonication using 500 watt ultrasonicator for 3 phases (10 min each). The ultrasonicated mixture was centrifuged at $4,000{ }^{*} \mathrm{~g}$ for $6 \mathrm{~min}$. Enzyme assay was carried out on both the supernatant and pellet, according to the method of Adachi et al. (1978).

Determination of the triton X-100 percentage suitable for solubilization of alcobol debydrogenase from the membrane fraction

The membrane fraction was suspended in $0.01 \mathrm{M}$ buffer, $\mathrm{pH}$ 6.0. Triton $\mathrm{X}-100$ was added in different concentrations of $0.05 \%, 0.1 \%, 0.2 \%, 0.3 \%, 0.4 \%$ and $0.5 \%$ to different test tubes. The suspensions were gently stirred for $3 \mathrm{~h}$ at $0{ }^{\circ} \mathrm{C}$ and centrifuged at $16,000 * \mathrm{~g}$ for $60 \mathrm{~min}$. The supernatant was obtained as a solubilized enzyme based on Albolhassan et al. (2007) protocol. Protein concentration and enzyme activity were determined on each of the solubilized enzyme. The percentage of triton X-100 that gave the highest enzyme activity was used for mass solubilization of the enzyme from membrane fraction following the same procedure described by Albolhassan et al. (2007).

\section{Alcohol debydrogenase assay}

The particulate alcohol dehydrogenase was assayed in vitro, in the presence of potassium ferricyanide as an electron acceptor and ethanol as the substrate. The rate of ferricyanide reduction to ferricyanide gives a quantitative amount of ethanol oxidation (Adachi et al., 1978). The reaction mixture contained $0.1 \mathrm{ml}$ potassium ferricyanide $(0.1 \mathrm{M}), 0.6 \mathrm{ml}$ Mcllvaine buffer (0.1 M, pH 4.0), $0.1 \mathrm{ml}$ tritonX-100 (10\%), $0.1 \mathrm{ml}$ ethanol $(1 \mathrm{M})$; thus the enzyme solution had a total volume of $1 \mathrm{ml}$. The reaction was carried out at $37^{\circ} \mathrm{C}$ by addition of ethanol solution and stopped by adding $0.5 \mathrm{ml}$ of ferric dopanol reagent. Thereafter, $3.5 \mathrm{ml}$ of water were further added to the reaction mixture and well mixed. The resulting stabilized Prussian blue colour formed was measured by spectrophotometer at $660 \mathrm{~nm}$ after standing for $20 \mathrm{~min}$ at $37^{\circ} \mathrm{C}$. One unit of the enzyme activity is defined as the amount of the enzyme catalyzing the oxidation of 1 umol 233 amount of the enzyme catalyzing the oxidation of $1 \mu \mathrm{mol}$ of ethanol per min under the assay conditions.

\section{Protein concentration estimation}

Protein concentration was determined by the method of Lowry et al. (1951). The reaction mixture contained $0.0-1.0$ $\mathrm{ml}$ protein stock solution ( $2 \mathrm{mg} / \mathrm{ml}$ Bovin Serum Albumin) in test tubes arranged in triplicates. The volume was made up to 1 $\mathrm{ml}$ with distilled water. For the test mixture, $0.1 \mathrm{ml}$ of the enzyme solution was mixed with $0.9 \mathrm{ml}$ of distilled water. In either case, $5 \mathrm{ml}$ of solution E (1:50 mixture of alkaline sodium carbonate solution and copper tetraoxosulphate (vi) solution) were added to each tube and allowed to stand at room temperature for $10 \mathrm{~min}$. Next, $0.5 \mathrm{ml}$ of solution $\mathrm{C}$ (dilute Folin-Ciocalteau phenol reagent) was added with rapid mixing After standing for $30 \mathrm{~min}$, absorbance was read at $750 \mathrm{~nm}$ using a UV spectrophotometer. Absorbance values were converted to protein concentration by extrapolation from the protein standard curve.

\section{Determination of percentage polyethelene glycol 6000 suitable} for precipitation of alcohol dehydrogenase from solution

To the solubilized enzyme solution, polyethelene glycol 6000 was added in different concentrations of $0 \%, 5 \%$, $10 \%, 15 \%, 20 \%, 25 \%$ and $30 \%$ to different test tubes containing the same volume of enzyme solution. After $30 \mathrm{~min}$ of stirring in an ice bath, the enzyme solution was centrifuged at $4,000^{*} \mathrm{~g}$ for $1 \mathrm{~h}$. The precipitate was suspended in the volume of $0.01 \mathrm{M}$ potassium phosphate and enzyme activity was determined for each of the concentration values. The concentration that gave the highest activity was used for mass precipitation of the enzyme.

\section{Sephadex G-50 column chromatography}

To the solubilised enzyme solution, polyethylene glycol 6000 (15\%) was added to mass precipitate the enzyme. After $30 \mathrm{~min}$ of stirring in an ice bath, the enzyme solution was centrifuged at $4,000^{*} \mathrm{~g}$ for $1 \mathrm{~h}$. The precipitate was suspended in $0.01 \mathrm{M}$ buffer $\mathrm{pH} 6.0$ and the thick suspension was introduced onto sephadex G-50 column for desalting. The enzyme was introduced onto sephadex G-50 packed column $(1.4 \times 61.50 \mathrm{~cm})$ preequilibrated with $0.01 \mathrm{M}$ potassium phosphate buffer, $\mathrm{pH} 6.0$. The packed column was washed with $1 \mathrm{~L}$ of the same buffer to remove non adsorbent materials. The protein was eluted with $0.02 \mathrm{M}$ potassium buffer, $\mathrm{pH}$ 6.0. The fractions with high alcohol dehydrogenase activity were pooled together for subsequent purification stage. Alcohol dehydrogenase activities from each of the eluted fractions were monitored at absorbance of $660 \mathrm{~nm}$ and protein absorbance read at $280 \mathrm{~nm}$.

\section{Sephadex G-200 gel filtration}

Sephadex G-200 column was prepared after swelling of 10 $\mathrm{g}$ of the gel in $500 \mathrm{ml}$ of water, for $48 \mathrm{~h}$. The pooled enzyme from the preceding stage was introduced onto sephadex G-200 packed column $(1.4 \times 61.50 \mathrm{~cm})$ pre-equilibrated with $0.01 \mathrm{M}$ potassium phosphate buffer, $\mathrm{pH}$ 6.0. The packed column was washed with $1 \mathrm{~L}$ of the same buffer to remove non adsorbent materials. The protein was eluted with $0.02 \mathrm{M}$ potassium buffer, $\mathrm{pH}$ 6.0. The fractions with high alcohol dehydrogenase activity were pooled and designated as the partially purified alcohol dehydrogenase. 
234

\section{Characterization of partially purified alcohol dehydrogenase}

\section{Effect of $p H$ on alcohol dehydrogenase activity}

The optimum $\mathrm{pH}$ for enzyme activity was determined using $0.05 \mathrm{M}$ sodium acetate buffer ( $\mathrm{pH} 3-4), 0.1 \mathrm{M}$ Mcllvain buffer ( $\mathrm{pH} 5-7$ ) and Tris-HCl buffer ( $\mathrm{pH} 8.0-10.0)$. Alcohol dehydrogenase activity was determined using $0.6 \mathrm{ml}$ of each of the buffers as earlier described in the assay method (Adachi $e t$ al., 1978).

\section{Effect of temperature on alcohol dehydrogenase activity}

The optimum temperature was determined by incubating the enzyme with alcohol solution at temperatures between 30 and $90^{\circ} \mathrm{C}$, for $20 \mathrm{~min}$ and at $\mathrm{pH}=5$ using $0.1 \mathrm{M} \mathrm{Mcllvain}$ buffer. The activity was then assayed by using the method described earlier in assay method (Adachi et al., 1978).

Effect of substrate concentration on alcohol dehydrogenast activity

The effect of substrate concentration on the activity of alcohol dehydrogenase was determined by incubating the enzyme with 20, 40, 60, 100, 120, 140, 160, 180 and $200 \mathrm{mM}$ concentration of ethanol at $\mathrm{pH} 5.0$ and $50^{\circ} \mathrm{C}$. The $\mathrm{V}_{\max }$ and $\mathrm{K}_{\mathrm{m}}$ values of the enzyme were determined using the Lineweaverburk plot.

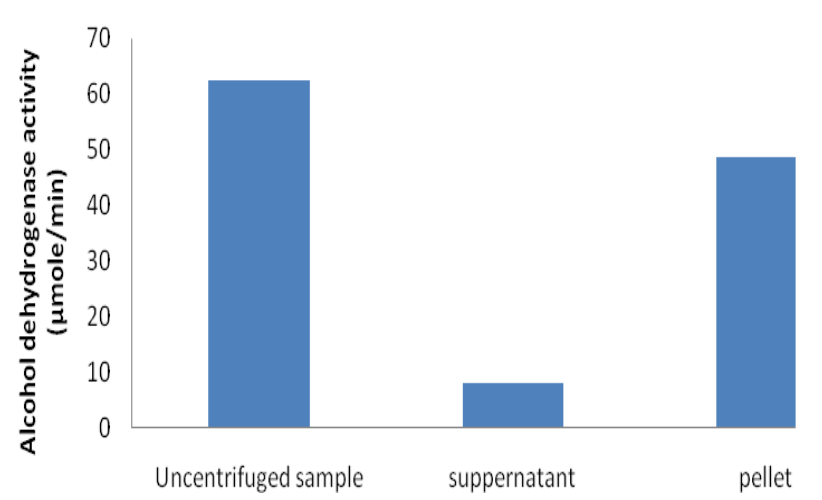

Fig. 1. Alcohol dehydrogenase activity after ultrasonication and centrifugation of the harvested cells

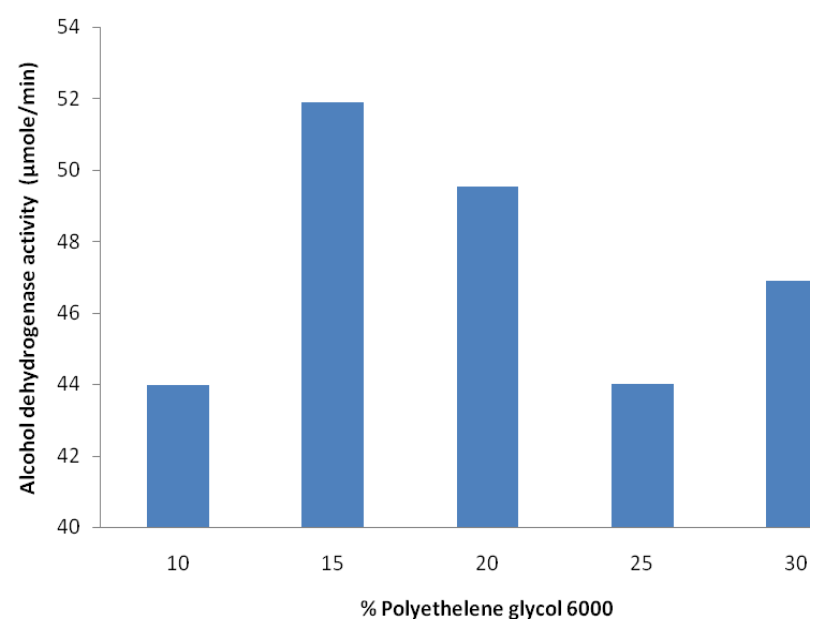

Fig. 3. Polyethelene glycol 6000 precipitation profile of alcohol dehydrogenase activity

\section{Results}

\section{Isolation of alcohol dehydrogenase from Acetobacter aceti}

The alcohol dehydrogenase activity observed in the supernatant was extremely low relative to the amount of protein present in the crude enzyme sample, while that in the pellet was high (Fig. 1). Solubilization of alcohol dehydrogenase with $0.3 \%$ triton-X-100 followed the triton X-100 solubilization profile as shown in Fig. 2. In the solubilization profile, $0.3 \%$ of triton X100 gave the highest alcohol dehydrogenase activity. Alcohol dehydrogenase activity increased by $475 \%$ in the supernatant after the solubilization with triton X-100.

\section{Partially purified alcohol dehydrogenase}

The alcohol dehydrogenase activity after precipitation was more intense at $15 \%$ polyethelylene glycol 6000 (Fig. 3). In the gel filtration using sephadex G-200, the highest peaks for alcohol dehydrogenase activity were obtained in tubes 19, 21 and 22. These tubes were pooled together and designated as partially purified alcohol dehydrogenase (Fig 4 and 5).

Effects of $p H$, temperature and substrate concentration on alcohol dehydrogenase

An optimum $\mathrm{pH}$ for alcohol dehydrogenase activity was 5 (pH 5) (Fig. 6). The result of temperature studies showed that as

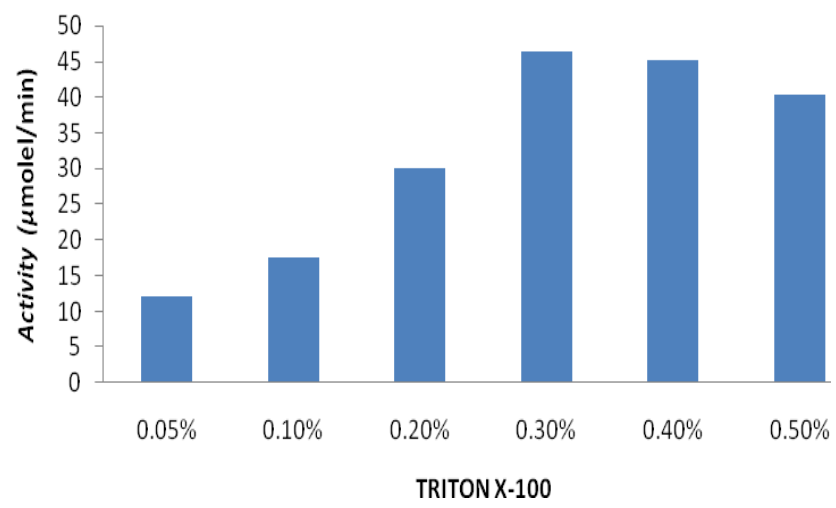

Fig. 2. Triton $\mathrm{X}-100$ solubilization profile of alcohol dehydrogenase

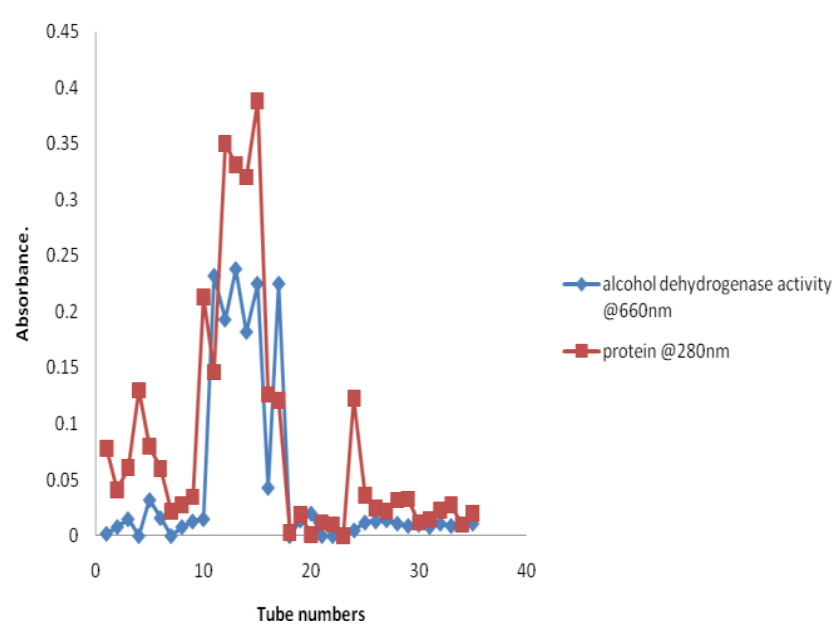

Fig. 4 Desalting using sephadex G-50 


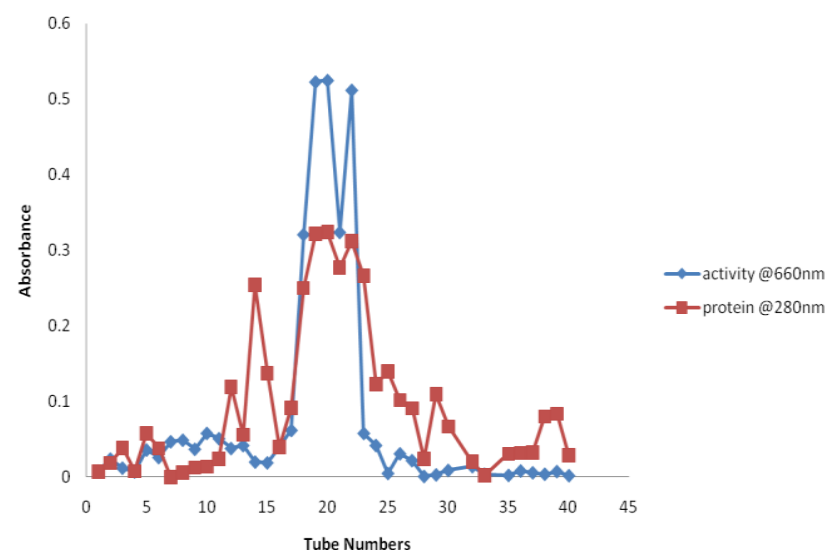

Fig. 5. Elution profile using sephadex G-200

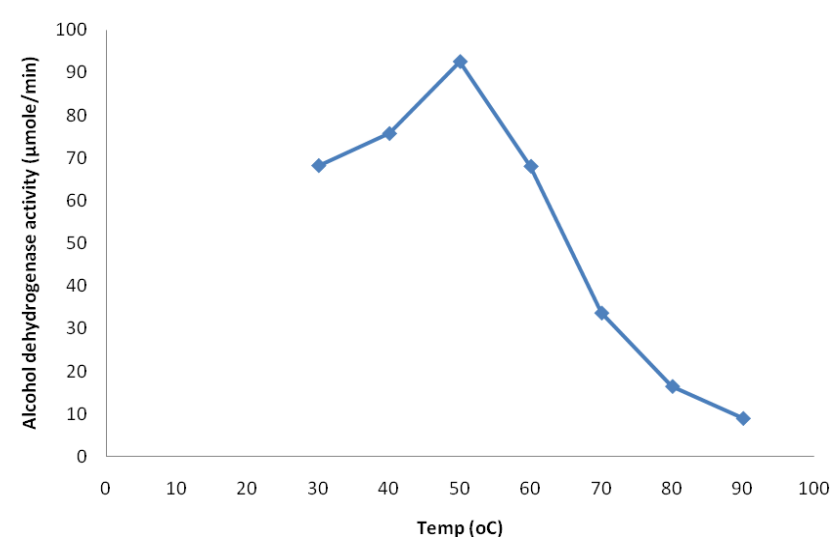

Fig. 7.Effect of temperature on the alcohol dehydrogenase activity

temperature increased from $30{ }^{\circ} \mathrm{C}$ to $50{ }^{\circ} \mathrm{C}$, the alcohol dehydrogenase activity increased and maximum alcohol dehydrogenase activity of $92.46 \mu \mathrm{mole} / \mathrm{min}$ was found at $50^{\circ} \mathrm{C}$. Further increase of the temperature beyond $50^{\circ} \mathrm{C}$ decreased the alcohol dehydrogenase activity till the end of incubation (Fig. 7). Alcohol dehydrogenase activity in this study increased with the ethanol concentration, until $120 \mathrm{mM}$ (Fig. 8). From this point, further increase in ethanol concentration did not significantly alter the activity of alcohol dehydrogenase.

\section{Discussion}

The observation of high alcohol dehydrogenase activity in the pellet e.g. membrane fraction, indicated that the enzyme was located in the cytoplasmic membrane, thus detergent was used in solubilizing the enzyme. The importance of detergents as tools for the study of membrane proteins cannot be underestimated (Annela, 2004). Integral membrane proteins that possess hydrophobic surfaces are more strongly associated with the bilayer and these intrinsic proteins extend across or are partially inserted into the lipid bilayer (Ohlendieck, 2004). Extraction of integral membrane proteins is commonly accomplished by solubilizing the protein-containing membrane fraction using variety of detergents (LeMaire et al., 2000).

Triton X-100 (0.3\%), a nonionic detergent, was the most suitable in solubilizing the palm wine alcohol dehydrogenase. Triton X-100 has been reported to be effective and at the same time does not denature proteins compared to other types of

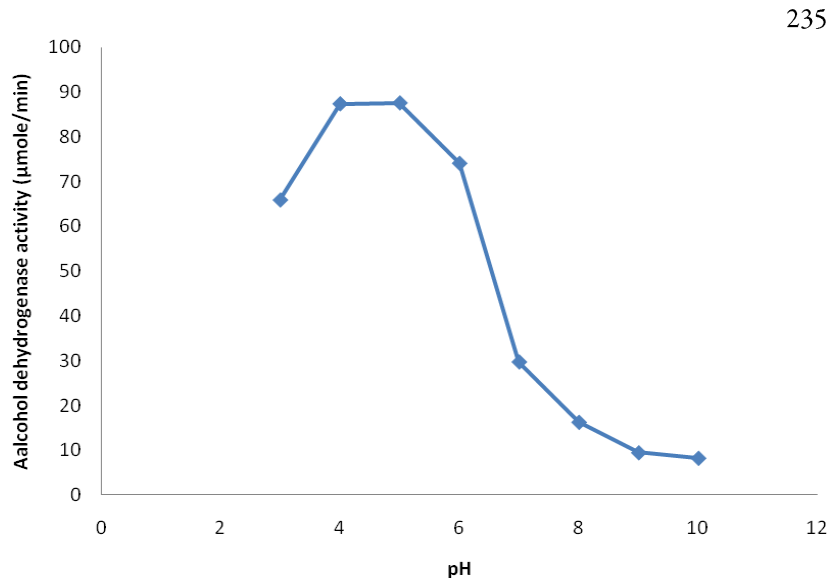

Fig. 6. Effect of $\mathrm{pH}$ on the alcohol dehydrogenase activity

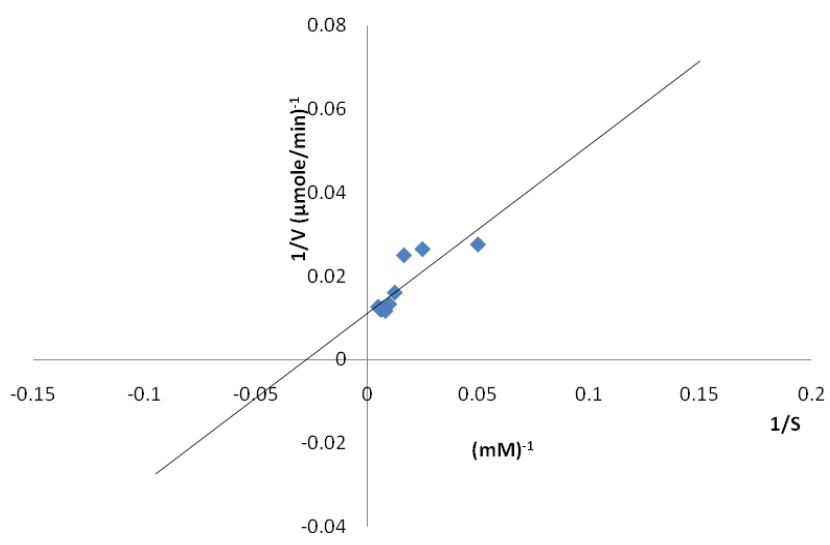

Fig. 8. Line weaver burk plot of alcohol dehydrogenase kinetics

detergent used for solubilization (Annela, 2004). Solubilization of alcohol dehydrogenase with $0.3 \%$ triton-X-100 followed the triton X-100 solubilization profile as shown in Fig. 2. In the solubilization profile, $0.3 \%$ of triton X-100 gave the highest alcohol dehydrogenase activity. This result was in agreement with the finding of Albolhassan et al. (2007) who used triton X-100 to solubilize alcohol dehydrogenase from Acetobacter. The low activity of alcohol dehydrogenase observed at higher concentration of triton X-100 could be due to the fact that the high concentration of the detergent inhibited the enzyme activity, probably by binding to the enzyme active site or by changing the protein conformation generally. In this study, alcohol dehydrogenase activity increased by $475 \%$ in the supernatant after the solubilization using triton X-100.

Polyethelene glycol 6000 (15\%) was most effective in precipitating the alcohol dehydrogenase. Polyethelene glycol 6000 is a non-ionic polymer of ethelene oxide of molecular weight 6000 Dalton. The use of non-ionic polymers for the precipitation is a method that can help prevent protein denaturation and assist in removal of detergents. Typically, larger proteins precipitate at lower concentrations of non-ionic polymers (Harrison, 1993). Polyethylene glycols are the preferred non-ionic polymers for protein precipitation because the viscosity of concentrated solutions is lower than other nonionic polymers (Harison, 1993). Polyethelene glycol is easily soluble in water due to the ether oxygen spread along the length of the polymer, which are strong Lewis bases and form hydrogen bonds with water molecules. In addition, the formation and equilibration of precipitates take significantly 
236

less time with polyethelene glycol as the precipitating agent than with ammonium sulfate or ethanol (Asenjo, 1990; Deutscher, 1990).

In the gel filtration using sephadex G-200, highest peaks for alcohol dehydrogenase activity were obtained in tubes 19, 21 and 22. These tubes were pooled together and designated as partially purified alcohol dehydrogenase. An optimum $\mathrm{pH}$ for alcohol dehydrogenase activity was 5 (pH 5) (Fig. 6). Occurrence of optimum $\mathrm{pH}$ at fairly acidic $\mathrm{pH}$ region is characteristics of this enzyme as vinegar fermenter. Albolhassan et al. (2007) and Adachi et al. (1978) reported pH optima of 4 for membrane-bound quinon protein, alcohol dehydrogenase from a native strain of Acetobacter.

The result of temperature studies showed that as temperature increased from $30{ }^{\circ} \mathrm{C}$ to $50{ }^{\circ} \mathrm{C}$, the alcohol dehydrogenase activity increased and maximum alcohol dehydrogenase activity of $92.46 \mu \mathrm{mole} / \mathrm{min}$ was found at $50^{\circ} \mathrm{C}$. Further increase in temperature beyond $50^{\circ} \mathrm{C}$ decreased the alcohol dehydrogenase activity till the end of incubation (Fig. 7). The decrease in enzyme activity at higher temperature may be due to enzyme denaturation. The adverse effect of high temperature on protein denaturation has been widely reported (Dayet al., 2002).

Alcohol dehydrogenase activity in this study increased as ethanol concentration increased until $120 \mathrm{mM}$ (Fig. 8). From this point, further increase in ethanol concentration did not significantly alter the activity of alcohol dehydrogenase. Thus, alcohol dehydrogenase active site became saturated at $120 \mathrm{mM}$ concentraction of ethanol. This implied that alcohol dehydrogenase obeys Michaelis-Menten equation and suggested that the activity of the enzyme can be regulated by ethanol concentration. This result is comparable to the studies made on alcohol dehydrogenase by Abolhassan et al. (2007) who reported the ethanol saturation concentration of $100 \mathrm{mM}$ at $\mathrm{pH}$ 4. The Michaelis-Menten constant $\left(\mathrm{K}_{\mathrm{m}}\right)$ and maximum velocity $\left(\mathrm{V}_{\text {max }}\right)$ for oxidation of ethanol by the alcohol dehydrogenase at $50^{\circ} \mathrm{C}$ and $\mathrm{pH}$ of 5 evaluated using Lineweaver-Burk plot yielded $36 \mathrm{mM}$ and $90.9 \mu \mathrm{mole} / \mathrm{min}$ respectively. The Michaelis-Menten constant $\left(\mathrm{K}_{\mathrm{m}}\right)$ is the concentration of substrate at which half the active site of an enzyme is filled. Thus, $K_{m}$ provides a measure of the substrate concentration required for significant catalysis to occur. The value of $K_{m}$ in this reaction $(36 \mathrm{mM})$ was very small. The low $K_{m}$ value suggested high affinity with which alcohol dehydrogenase binds with ethanol. It indicated that the enzyme required small amount of substrate to become saturated. Hence, the maximum velocity $\left(\mathrm{V}_{\max }=90.9\right.$ $\mu \mathrm{mole} / \mathrm{min}$ ) was reached at relatively low substrate (ethanol) concentration. This may explain why palm wine deterioration was quick.

\section{Conclusions}

In conclusion, the detergent, triton X-100 (0.3\%) and the salt, polyethelene glycol $6000(15 \%)$ respectively were effective in solubilization of alcohol dehydrogenase from the cell membrane and precipitation of alcohol dehydrogenase from solution. The low activity of alcohol dehydrogenase at a low $\mathrm{pH}$, noted at low and high temperatures, showed that both $\mathrm{pH}$ and temperature of palm wine can be manipulated as such to modulate the catalytic activity of the alcohol dehydrogenase and maintain the organoleptic characteristics of the palm wine.

\section{References}

Abolhassan MF, SepehrS, Islami M, Shabani A, Soudi MR, Moosavi-Nejad SZ (2007). Purification and characterization of membrane-bound quinoprotein alcohol dehydrogenase from a native strain of Acetobacter. Journal of Biological Sciences 7(2):315-320.

Adachi O, Miyagawa E, Shinagawa E, Matsushita K, Ameyama M (1978). Purification and properties of particulate alcohol dehydrogenase from Acetobacter aceti. Agricultural and Biological Chemistry 42(12):23312340.

Amoa-Awua WK, Sampson E Tano-Debrah K (2007). Growth of yeasts, lactic and acetic acid bacteria in palm wine during tapping and fermentation from felled oil palm (Elaeis guneensis) in Ghana. Journal of Applied Microbiology 102(2):599-606.

Annela M, Seddon PC, Paula JB (2004). Membrane proteins, lipids and detergents: not just a soap opera. Biochimica et Biophysica Acta Biomembranes 1666(1):105-117.

Asenjo JA (1990). Separation processes in biotechnology, Marcel Dekker New York, pp 329-358.

Bechem EET, Omoloko C, Nwaga D, Titanji VPK (2007) Characterization of palm wine yeasts using osmiotic, ethanol tolerance and the isozyme polymorphism of alcohol dehydrogenase. African Journal of Biotechnology6(14):1715-1719.

Day R, Bennion BJ, Ham S, Daggett V (2002). Increasing temperature accelerates protein unfolding without changing the pathway of unfolding.Journal of Molecular Biology 322(1):189-203.

Deutscher MP (1990). Methods in enzymology, Vol 182, Guide to Protein Purification. Academic Press, New Yorkpp 285-306.

Enwefa C, Uwajeh R, Oduh R(2004). Some studies on Nigerian palm wine with special reference to yeasts. Acta Biotechnologica 12(2):117-125.

Harrison-Roger G (1993). Protein purification process engineering Marcel Dekker,New Yorkpp 115-208.

LeMaire M, Champeil P, Moller JV (2000). Interaction of membrane proteins and lipids with solubilizing detergents. Biochimica et Biophysica Acta(BBA-) Biomembranes 1508:86-111.

Lowry OH, Rosebrough NJ, Farr AL, Randall RJ (1951). Protein measurements with follin-phenol reagents. Journal of Biological Chemistry 193(1):265-275.

Maal KB, Shafiee R (2010). Characterization of an Acetobacterstrain isolated from Iranian Peach that tolerates high temperatures and ethanol concentration. International Journal of Medical Sciences 1:1-14.

Ohlendieck K (2004). Extraction of membrane protein. Protein Purification Protocol 244:283-293.

Ojimelukwe PC (2002). Effect of preservation with Saccoglottis gabonesis on the microbiology of fermenting palm wine. Journal of Food Biochemistry25(5):411-424.

Onwuka UN (2011). Performance evaluation of Ohmic heating under a static medium on the pasteurization and quality parameters of palm wine (Raphia hokeri). Journal of Emerging Trends in Egineering and Applied Sciences 2(1):160-165.

Opara CC, Ajoku G, Madumelu NO (2013). Palm wine mixed culture fermentation kinetics. Greener Joumal of Physical Science 3(1):028037. 